\title{
A global agenda for advancing freshwater biodiversity research
}

\section{Alain Maasri, ${ }^{1,2}$ (D)}

Claudio Baigun ${ }^{6}$

Lee E. Brown ${ }^{10}$ ()

\author{
Sonja C. Jähnig ${ }^{1,3}$
}

Donald J. Baird ${ }^{7}$ (1)

Qinghua Cai ${ }^{11}$

Topiltzin Contreras-MacBeath ${ }^{14}$

\author{
Mihai
}

Angelica Batista-Morales 8
Rita Adrian ${ }^{1,5}$ (1)

Núria Bonada 9 (1) |

Gonzalo Delacámara $^{17}$ | Luc De Meester ${ }^{1,5,18}$ @ | Klaus-Douwe B. Dijkstra ${ }^{19}$

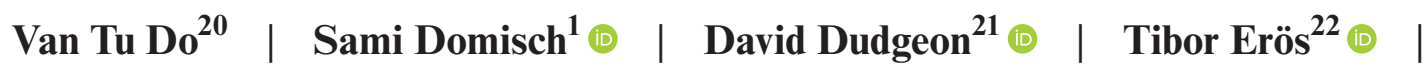

Hendrik Freitag $^{23} \odot$ ～Joerg Freyhof ${ }^{24}$ ｜ Jana Friedrich ${ }^{25}$ | Martin Friedrichs-Manthey ${ }^{1,5}$ |

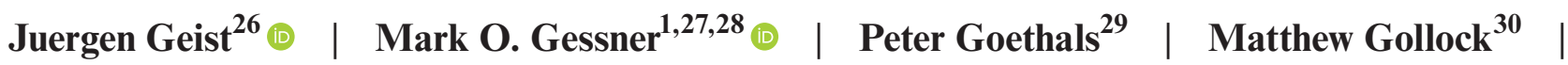

Christopher Gordon $^{31} \odot$ | Hans-Peter Grossart ${ }^{1,28,32}$ | Georges Gulemvuga $^{33}$ |

Pablo E. Gutiérrez-Fonseca ${ }^{34}$ @ | Peter Haase $^{13,35}$ @ | Daniel Hering ${ }^{35}$

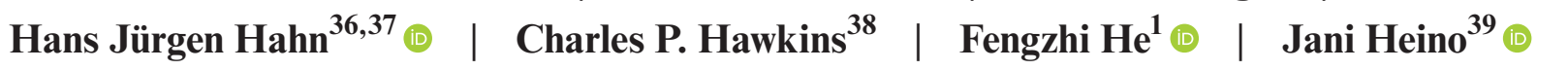

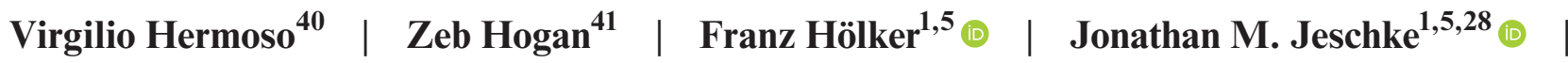

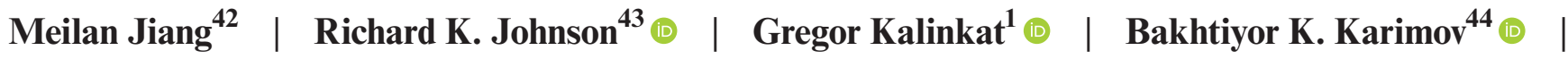

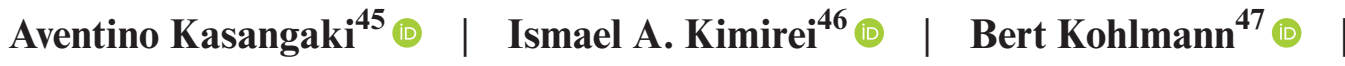

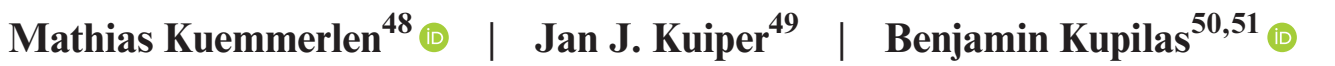

Simone D. Langhans ${ }^{52,53}$ @ | Richard Lansdown ${ }^{54}$ | Florian Leese $^{35}$ (1) |

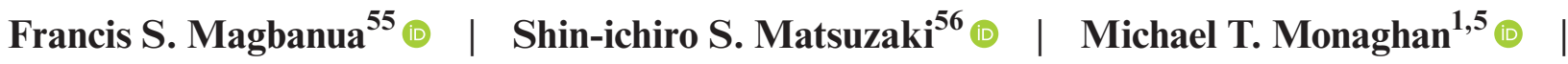

Levan Mumladze $^{57}$ @ | Javier Muzon ${ }^{58}$ | Pierre A. Mvogo Ndongo ${ }^{59}$ |

Jens C. Nejstgaard ${ }^{1,28}$ | Oxana Nikitina ${ }^{60}$ | Clifford Ochs ${ }^{61}{ }^{6}$ |

Oghenekaro Nelson Odume ${ }^{62} \odot$ | Jeffrey J. Opperman ${ }^{63}$ | Harmony Patricio ${ }^{64}$ |

Steffen U. Pauls ${ }^{13,65}$ | Rajeev Raghavan ${ }^{66}$ | Alonso Ramírez ${ }^{67}$ | Bindiya Rashni ${ }^{68}$ |

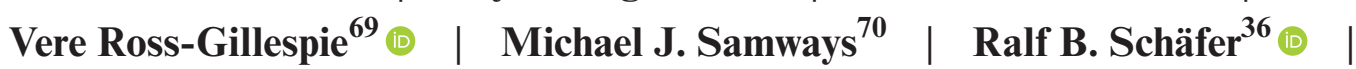

Astrid Schmidt-Kloiber ${ }^{71} \odot$ ｜ Ole Seehausen ${ }^{72,73}$ @ | Deep Narayan Shah ${ }^{74}$ |

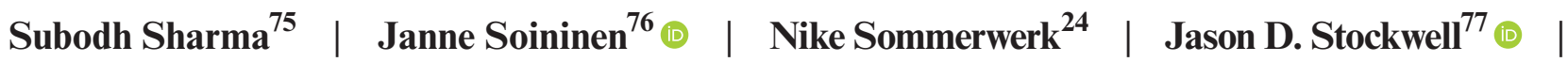

Frank Suhling $^{78}$ | Ram Devi Tachamo Shah ${ }^{79}$ | Rebecca E. Tharme ${ }^{80,81}$ @ James

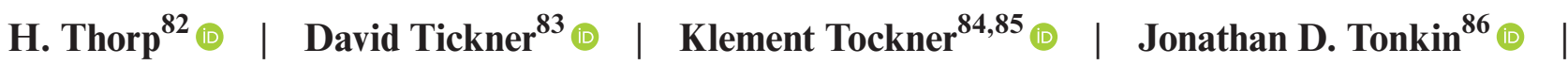

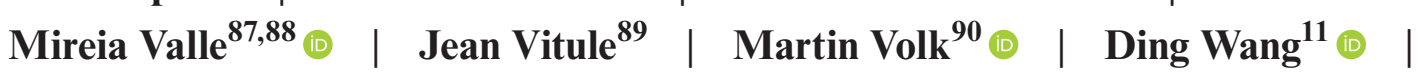

Christian Wolter $^{1}{ }^{\circledR}$ | Susanne Worischka ${ }^{36}{ }^{3}$ 
${ }^{1}$ Leibniz Institute of Freshwater Ecology and Inland Fisheries, Berlin, Germany

${ }^{2}$ The Academy of Natural Sciences of Drexel University, Philadelphia, Pennsylvania, USA

${ }^{3}$ Humboldt-Universität zu Berlin, Berlin, Germany

${ }^{4}$ Research Center in Systems Ecology and Sustainability, University of Bucharest, Bucharest, Romania

${ }^{5}$ Institut für Biologie, Freie Universität Berlin, Berlin, Germany

${ }^{6}$ Universidad Nacional de San Martin, San Martin, Argentina

${ }^{7}$ Environment \& Climate Change Canada/University of New Brunswick, Fredericton, New Brunswick, Canada

${ }^{8}$ Instituto de Investigación de Recursos Biológicos Alexander von Humboldt, Bogotá, Colombia

${ }^{9}$ Institut de Recerca de la Biodiversitat (IRBio), Universitat de Barcelona, Barcelona, Spain

${ }^{10}$ School of Geography \& water@1eeds, University of Leeds, Leeds, UK

${ }^{11}$ Institute of Hydrobiology, Chinese Academy of Sciences, Wuhan, China

${ }^{12}$ Norwegian University of Life Sciences, Ås, Norway

${ }^{13}$ Senckenberg Research Institute and Natural History Museum, Frankfurt am Main, Germany

${ }^{14}$ Universidad Autónoma del Estado de Morelos, Cuernavaca, Mexico

${ }^{15}$ Carleton University, Ottawa, Ontario, Canada

${ }^{16}$ UR RiverLy, INRAE, Villeurbanne, France

${ }^{17}$ IMDEA Water Institute, Madrid, Spain

${ }^{18}$ Katholieke Universiteit Leuven, Leuven, Belgium

${ }^{19}$ Naturalis Biodiversity Center, Leiden, The Netherlands

${ }^{20}$ Institute of Ecology and Biological Resources, Vietnam Academy of Science and Technology, Ha Noi, Vietnam

${ }^{21}$ The University of Hong Kong, Hong Kong, China

${ }^{22}$ Balaton Limnological Research Institute, Tihany, Hungary

${ }^{23}$ Ateneo de Manila University, Quezon City, Philippines

${ }^{24}$ Museum für Naturkunde—Leibniz Institute for Evolution and Biodiversity Science, Berlin, Germany

${ }^{25}$ Helmholtz-Zentrum Hereon, Geesthacht, Germany

${ }^{26}$ Technical University of Munich, Freising, Germany

${ }^{27}$ Berlin Institute of Technology, Berlin, Germany

${ }^{28}$ Berlin-Brandenburg Institute of Advanced Biodiversity Research (BBIB), Berlin, Germany

${ }^{29}$ Ghent University, Gent, Belgium

${ }^{30}$ Zoological Society of London, London, UK

${ }^{31}$ University of Ghana, Accra, Ghana

${ }^{32}$ Institute of Biochemistry and Biology, University of Potsdam, Potsdam, Germany

${ }^{33}$ International Commission for Congo-Ubangui-Sangha Basin, Kinshasa, D.R. Congo

${ }^{34}$ University of Costa Rica, San José, Costa Rica

${ }^{35}$ University of Duisburg-Essen, Essen, Germany

${ }^{36}$ University of Koblenz-Landau, Koblenz and Landau, Germany

${ }^{37}$ Institute for Groundwater Ecology IGÖ GmbH, Landau, Germany

${ }^{38}$ Utah State University, Logan, Utah, USA

${ }^{39}$ Finnish Environment Institute, Oulu, Finland

${ }^{40}$ Centre de Ciència i Tecnologia Forestal de Catalunya, Solsona, Spain

${ }^{41}$ University of Nevada, Reno, Nevada, USA

${ }^{42}$ Chongqing University of Posts and Telecommunications, Chongqing, China

${ }^{43}$ Swedish University of Agricultural Sciences, Uppsala, Sweden

${ }^{44}$ Tashkent Institute of Irrigation and Agricultural Mechanization Engineers, Tashkent, Uzbekistan

${ }^{45}$ Kabale University, Kabale, Uganda

${ }^{46}$ Tanzania Fisheries Research Institute, Dar es Salaam, Tanzania

${ }^{47}$ EARTH University, San José, Costa Rica

${ }^{48}$ Trinity College Dublin, The University of Dublin, Dublin, Ireland

${ }^{49}$ Stockholm Resilience Centre, Stockholm University, Stockholm, Sweden

${ }^{50}$ Norwegian Institute for Water Research, Oslo, Norway

${ }^{51}$ University of Münster, Münster, Germany

${ }^{52}$ Basque Centre for Climate Change (BC3), Leioa, Spain

${ }^{53}$ University of Otago, Dunedin, New Zealand

${ }^{54}$ IUCN Species Survival Commission, Cambridge, UK

${ }^{55}$ University of the Philippines Diliman, Quezon City, Philippines

${ }^{56}$ National Institute for Environmental Studies, Tsukuba, Japan

${ }^{57}$ Institute of Zoology, Ilia State University, Tiblis, Georgia 
${ }^{58}$ Universidad Nacional de Avellaneda, Avellaneda, Argentina

${ }^{59}$ Université de Douala, Douala, Cameroon

${ }^{60}$ WWF-Russia, Moscow, Russia

${ }^{61}$ University of Mississippi, University Park, Mississippi, USA

${ }^{62}$ Rhodes University, Makhanda, South Africa

${ }^{63}$ World Wildlife Fund, Washington, District of Columbia, USA

${ }^{64}$ Global Wildlife Conservation, Austin, Texas, USA

${ }^{65}$ Justus-Liebig-University, Gießen, Germany

${ }^{66}$ Kerala University of Fisheries and Ocean Studies, Kochi, India

${ }^{67}$ North Carolina State University, Raleigh, North Carolina, USA

${ }^{68}$ Institute of Applied Science, University of the South Pacific, Suva, Fiji

${ }^{69}$ NatureMetrics Ltd, Surrey, UK

${ }^{70}$ Stellenbosch University, Stellenbosch, South Africa

${ }^{71}$ University of Natural Resources and Life Sciences, Vienna, Austria

${ }^{72}$ University of Bern, Bern, Switzerland

${ }^{73}$ Swiss Federal Institute of Aquatic Science and Technology (Eawag), Kastanienbaum, Switzerland

${ }^{74}$ Tribhuvan University, Kirtipur, Nepal

${ }^{75}$ Kathmandu University, Kathmandu, Nepal

${ }^{76}$ University of Helsinki, Helsinki, Finland

${ }^{77}$ University of Vermont, Burlington, Vermont, USA

${ }^{78}$ Technische Universität Braunschweig, Braunschweig, Germany

${ }^{79}$ Kathmandu University, Dhulikhel, Nepal

${ }^{80}$ Riverfutures, Buxton, UK

${ }^{81}$ Université de Tours, Tours, France

${ }^{82}$ University of Kansas, Lawrence, Kansas, USA

${ }^{83}$ WWF-UK, Woking, UK

${ }^{84}$ Senckenberg Society for Nature Research, Frankfurt am Main, Germany

${ }^{85}$ Goethe University, Frankfurt am Main, Germany

${ }^{86}$ School of Biological Sciences, University of Canterbury, Christchurch, New Zealand

${ }^{87}$ National Center for Ecological Analysis and Synthesis, University of California, Santa Barbara, California, USA

${ }^{88}$ AZTI, Marine Research, Basque Research and Technology Alliance (BRTA), Sukarrieta, Spain

${ }^{89}$ Federal University of Paraná, Curitiba, Brazil

${ }^{90}$ Helmholtz Centre for Environmental Research-UFZ, Leipzig, Germany

\section{Correspondence}

Alain Maasri and Sonja Jähnig, Leibniz Institute of Freshwater Ecology and Inland Fisheries, Department of Ecosystem Research, Müggelseedamm 310, 12587 Berlin, Germany.

Email: alainmaasri@gmail.com and sonja.jaehnig@igb-berlin.de

Editor: Peter Thrall

\begin{abstract}
Global freshwater biodiversity is declining dramatically, and meeting the challenges of this crisis requires bold goals and the mobilisation of substantial resources. While the reasons are varied, investments in both research and conservation of freshwater biodiversity lag far behind those in the terrestrial and marine realms. Inspired by a global consultation, we identify 15 pressing priority needs, grouped into five research areas, in an effort to support informed stewardship of freshwater biodiversity. The proposed agenda aims to advance freshwater biodiversity research globally as a critical step in improving coordinated actions towards its sustainable management and conservation.
\end{abstract}

\section{K E Y W O R D S}

data infrastructure, ecology, freshwater biodiversity crisis, freshwaters, management, monitoring, research priorities, social ecology
Freshwater biodiversity encompasses the genes, populations, species, communities and ecosystems of all freshwaters, and provides essential ecosystem services that are fundamental for human livelihoods and well-being (Dudgeon et al., 2006). This biodiversity is currently declining at unprecedented rates (IPBES, 2019). The most recent Living Planet Report (WWF, 2020) documents an average $84 \%$ decline in abundances-within less than 50 years-for 3741 monitored populations representing 944 freshwater vertebrate species. This is 
the steepest decline in the three major realms of land, oceans and freshwaters, and underlines the disproportionate threat to freshwater biodiversity. Despite this unprecedented and ongoing decline, research on and conservation of freshwater biodiversity have been insufficiently prioritised. International and intergovernmental science-policy platforms, funding agencies and major philanthropy initiatives continue to fall short of giving freshwater biodiversity its rightful place in global biodiversity, climate and socioeconomic forums (Darwall et al., 2018; Heino et al., 2021; Tickner et al., 2020). For instance a recent report on environmental funding by 127 European foundations (Moralis, 2021) shows that freshwaters received a mere $1.75 \%$ of $€ 745$ million (US\$ 873 million) in environmental grants awarded in 2018 and ranked next-to-last among the 13 thematic-issue categories used to assess grant distribution.

Here, we propose an agenda for advancing freshwater biodiversity research globally. We view this as a critical step in supporting and improving globally coordinated actions towards the sustainable management and conservation of freshwaters. Our agenda aims to inform funding provision and provide guidance to civil society, philanthropic organisations and governmental agencies. We also encourage scientists, conservation practitioners, environmental managers and policymakers to engage with one another to support informed global freshwater biodiversity stewardship. Indeed, research priorities for sustainable management and conservation should be guided by management and conservation needs. We identify 15 priority needs grouped into five major integrated research areas designed to support conservation and management actions (Figure 1). Acknowledging that the 15 priority needs reflect different types of challenges, we grouped the challenges into three categories (Figure 2) summarising: (i) knowledge gaps that result from limited research, disparities in access to information or both; (ii) insufficient communication and exchange among scientists, practitioners, managers and policy makers and (iii) inadequate policy, lack of political will or the decoupling of current policy from demonstrated best practices for preserving and recovering freshwater biodiversity and the services it provides. We therefore identify the main challenges as a first step towards overcoming the current barriers. The agenda is not exhaustive of all priority needs and does not seek to rank them. We are aware that additional global challenges exist, including numerous local and regional disparities.

Our agenda reflects the collective opinion of the authors and grew from a consultation conducted in 2020 among a diverse panel of freshwater biodiversity researchers (Supporting Information). The consultation provided a platform for discussing and facilitating the exchange of ideas. The priority needs presented here are an extension of the consultation results. The authors of this agenda represent researchers and policy advocates from 38 countries, 18 (47\%) of them considered Global South countries. Out of the 96 authors, 28 (29\%) are affiliated with universities and research institutes in the Global South, and 16 (17\%) self-identify as currently co-creating freshwater biodiversity management and conservation in association with indigenous peoples.

\section{A Global Agenda for Advancing Freshwater Biodiversity Research}

\begin{tabular}{|c|c|c|}
\hline \multicolumn{2}{|c|}{ Ecology } & \multirow[b]{2}{*}{ Management } \\
\hline Monitoring & \multirow{4}{*}{$\begin{array}{c}\text { biodiversity and ecosystem services (A), study } \\
\text { the responses of biodiversity to multiple } \\
\text { stressors (B), investigate the ecological } \\
\text { and evolutionary responses of organisms, } \\
\text { communities and ecosystems } \\
\text { to global change (C) }\end{array}$} & \\
\hline $\begin{array}{l}\text { Coordinate existing and establish new } \\
\text { programs (A), identify and tackle gaps in } \\
\text { biodiversity knowledge (B), develop new } \\
\text { innovative methods for biodiversity } \\
\text { monitoring (C) }\end{array}$ & & $\begin{array}{l}\text { Thoroughly evaluate restoration } \\
\text { measures (A), develop management } \\
\text { strategies in line with "Nature Futures" } \\
\text { scenarios (B), establish perspectives on } \\
\text { management and ecologically compatible } \\
\text { dam building and operation schemes (C) }\end{array}$ \\
\hline Data infrastructure & & Social ecology \\
\hline $\begin{array}{c}\text { Establish a comprehensive overview } \\
\text { of data outlets (A), effectively } \\
\text { mobilize and digitize existing } \\
\text { data (B), develop accessible } \\
\text { databases according to principles } \\
\text { of Findability, Accessibility, Inter- } \\
\text { operability and Reusability (C) }\end{array}$ & & $\begin{array}{l}\text { Strengthen integration of social } \\
\text { sciences in biodiversity } \\
\text { research (A), better evaluate trade- } \\
\text { offs between ecological, economic, } \\
\text { and societal needs (B), systemati- } \\
\text { cally develop citizen science and } \\
\text { participatory research (C) }\end{array}$ \\
\hline
\end{tabular}

F I G U R E 1 A global agenda for advancing freshwater biodiversity research, consisting of 15 priority needs grouped into five major research areas, all aiming to support research for conservation and management actions. A, B and C correspond to the priority needs as described in the text below 


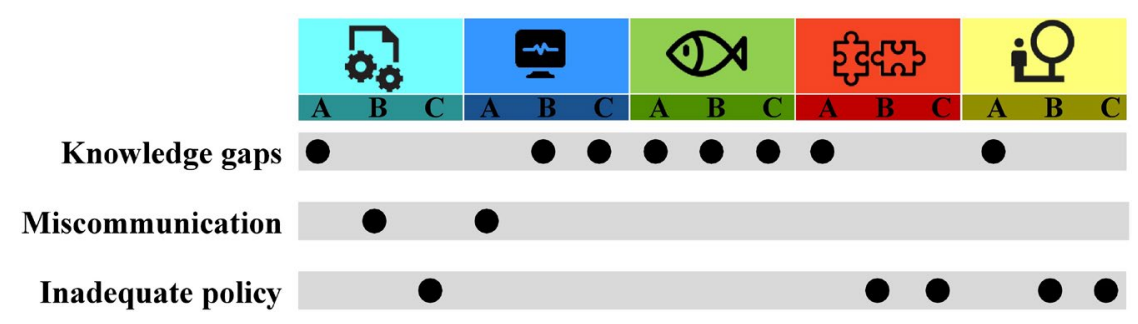

F I G U R E 2 Three main challenges (listed on the left) associated with the global priority needs identified to advance freshwater biodiversity research. Knowledge gaps correspond to limited research, disparities in access to information or both; miscommunication corresponds to insufficient communication and exchange among scientists, practitioners, managers and policy makers; and inadequate policy corresponds to deficient policy, lack of political will or the decoupling of current policy from demonstrated best practices for preserving and recovering freshwater biodiversity and the services it provides. A, B and C correspond to the priority needs identified in each of the five research areas as described in the text below

Consequently, we believe that the proposed agenda, with its 15 priority needs, reflects a representative diversity of opinions and constitutes a global synthesis of major priorities for advancing freshwater biodiversity research.

\section{DATA INFRASTRUCTURE}

Establish and empower information hubs for the acquisition, mobilisation, integration and provision of data across all areas of freshwater biodiversity research. Identified priority needs include:

A Establish a comprehensive compilation of data sources on freshwater biodiversity and work towards integrating them. This is an essential step for selecting a tractable number of efficient data outlets. Prioritise the use of existing platforms where metadata are available (e.g. the Global Biodiversity Information Facility or the Freshwater Information Platform), so that robust and verifiable protocols for data processing, handling and validation can be implemented (Nesshöver et al., 2016; Stephenson \& Stengel, 2020).

B Mobilise and share existing data to facilitate the coproduction of biodiversity and conservation research with the wider stakeholder and rights-holder communities. This effort should be accompanied by the digitisation of data from regional and national monitoring agencies, museum collections and research institutions (Ball-Damerow et al., 2019). Special attention should be given to non-English-language sources, which tend to be neglected in global meta-analyses (Konno et al., 2020).

C Develop accessible databases according to the FAIR principles of Findability, Accessibility, Interoperability and Reusability (Wilkinson et al., 2016), in addition to the Nagoya Protocol on access to genetic resources (Buck \& Hamilton, 2011) and any future agreements concerning genetic and digital resources. As the global community increasingly relies on computational support to process large data, this step is fundamental to increasing data availability and usage by scientists, environmental managers, conservation practitioners and other associated stakeholders and rights-holders.

\section{MONITORING}

Implement strategic programmes that efficiently and comprehensively document the status and trends of freshwater biodiversity. Identified priority needs include:

A Coordinate existing freshwater biodiversity monitoring programmes to increase the efficiency of ongoing monitoring activities, with the aim of achieving a globally consistent approach to collecting and assessing biodiversity data (Turak et al., 2017). This should be accompanied by the development of probabilistic survey designs to infer the global status of freshwater biodiversity (Hawkins \& Yuan, 2016) and enhance integration across locations (e.g. Long Term Ecological Research Network [LTER] and Global Lake Ecological Observatory Network [GLEON] sites).

B Enhance the taxonomic, ecological and genomic knowledge of freshwater organisms to increase coverage of efficient monitoring across organismal groups and geographical areas. This endeavour will directly benefit biodiversity monitoring specifically and biodiversity research in ecology at large. Special attention should be given to parasites, fungi, protists and other neglected taxa often described as 'hidden biodiversity' (Mlot, 2004).

C Develop and improve methodologies to overcome the taxonomic limitations and inefficiencies of monitoring programmes (Baird \& Hajibabaei, 2012; Rimet et al., 2021). Such methodologies include (i) omics approaches based on DNA, RNA, proteins and the full suite of metabolites; (ii) optic and acoustic recordings ranging from automated image and video analyses supported by artificial intelligence to remote-sensing 
technologies involving drone, airplane and satellite imagery and (iii) biodiversity informatics, citizen science and other emerging approaches that can gather and process large amounts of information. Additionally, new developments need to capture dimensions of freshwater biodiversity beyond the traditional concepts of species diversity, notably inter and intraspecific genomic diversity, species interactions that modulate distribution patterns of species in freshwater communities, ecosystem functioning and ecosystem services and habitat diversity at local to global scales.

\section{ECOLOGY}

Strengthen research on freshwater biodiversity and its ecological context, which is fundamental to conservation and management, as are the interactions among organisms and the environment that determine responses to global change. Identified priority needs include:

A Further identify relationships among biodiversity, ecosystem functioning and nature's contributions to people (Díaz et al., 2018; Dudgeon, 2010; Vári et al., 2021). This requires developing a mechanistic understanding of these relationships, integrating the multidimensionality of the role of biodiversity in ecosystem processes and improving process-based models (Tonkin et al., 2019) for freshwater biodiversity and their contribution to human well-being.

B Establish cause-and-effect relationships to understand and predict the responses of biodiversity to multiple stressors (Birk et al., 2020) and the release from such stressors. Field and system-wide experimentation that draws on short- (1-3 years) and long-term ( $>20$ years) studies, with associated funding streams, will be necessary to understand the dynamics of change, coupled with modelling to develop future scenarios.

$\mathrm{C}$ Explore the acclimation, evolutionary and evasion potentials of organisms (Merilä \& Hendry, 2014), and the associated ecosystem responses to global change (Heino et al., 2009; Kelly, 2019; Orr et al., 2021; Urban et al., 2016). Targeted field surveys will be most effective when combined with coordinated multi-site experiments through global research networks and spatially explicit modelling (Alberti et al., 2020). Experiments must go beyond small-scale mesocosm and microcosm studies, to include large-scale enclosures and exclosures, whole lakes, streams, wetlands and entire catchments. The coordination will crucially require creative funding mechanisms to establish, maintain and facilitate effective exchange among long-term and large-scale experimental platforms (e.g. AQUACOSM, a European network of mesocosm facilities for research on marine and freshwater ecosystems open for global collaboration).

\section{MANAGEMENT}

Enhance science-based strategies and methods for sustainable freshwater biodiversity management, and ensure that research data, information and knowledge can be easily accessed by managers and conservation practitioners. Identified priority needs include:

A Improve outcome assessment of restoration measures using large-scale replication of before-after-controlimpact designs, a practice still far from being common in current management practices (Geist \& Hawkins, 2016). Additionally, meta-analyses of results from long-term post-monitoring phases will be essential to assess restoration success and failures, enabling improved design of future restoration programmes to recover freshwater biodiversity ( $\mathrm{Lu}$ et al., 2019).

B Develop models and projections in line with the scenarios for Nature Futures (IPBES, 2016; Rosa et al., 2017) to shift traditional ways of forecasting human impacts on nature to nature-centred visions that integrate social-ecological interlinkages across biodiversity, ecosystem functions and services and human well-being (Kim et al., 2021; Pereira et al., 2020).

C Develop and test landscape- and catchment-based management and restoration programmes that explicitly consider lakes, rivers, ponds and wetlands. This includes environmentally and ecologically compatible dam schemes to minimise negative impacts. Given the current global surge in hydropower dam construction and planning, and acknowledging the wealth of literature available on the impacts of dams on freshwaters (Reid et al., 2019; Thieme et al., 2021; Zarfl et al., 2019), it is fundamental to implement evidence-based guidelines for improving dam building and operation to preserve ecological connectivity. As a broad guiding principle, evidence-based strategies need to be implemented to enhance blue infrastructure and preserve the associated ecosystem services provided by freshwater biodiversity.

\section{SOCIAL ECOLOGY}

Design conservation strategies that account for the societal responses to biodiversity change, and consider the social, cultural and economic context of protecting and recovering freshwater biodiversity. Identified priority needs include:

A Develop solutions for conflicts between biodiversity conservation and the human use of freshwaters and their catchments, and foster social-ecological approaches that integrate cultural and societal practices in knowledge co-production (Chambers et al., 2021; Norström et al., 2020). In doing so, it is important to acknowledge the shifting baseline 
syndrome (Humphries \& Winemiller, 2009; Soga \& Gaston, 2018), which refers to the shifts in people's perception of reference states when examining how humans value freshwater biodiversity, while ensuring its preservation and restoration in the future.

B Address trade-offs among ecological, economic and societal targets by concurrently engaging local communities, scientists and policymakers to develop adaptive management strategies and measures to protect freshwater biodiversity. This includes embracing traditional and indigenous ecological knowledge (Heino et al., 2020).

C Systematically develop citizen science (Fritz et al., 2019; McKinley et al., 2017) and participatory research to harness the societal competencies and workforce extending beyond academia and government authorities. This should include developing and sharing new experimental approaches that can be upscaled at low cost. Furthermore, due attention should be given to involving dedicated citizen experts (Eitzel et al., 2017), a tremendously valuable and yet often overlooked resource, to advance freshwater biodiversity research.

The ambitious agenda we propose is intended to initiate and advance the strategic development of freshwater biodiversity research and to further support efforts that are underway. Addressing the 15 priority needs entails increased collaboration and cooperation among stakeholders if we expect to satisfy the growing demands humans place upon freshwater ecosystems while ensuring that enough water of sufficient quality remains to sustain them. A stronger political commitment will be necessary to accompany freshwater biodiversity conservation as the critical global biodiversity crisis requires the definition of bold goals and the mobilisation of substantial resources to meet the challenges. By identifying the most pressing needs to counter the freshwater biodiversity loss, our agenda is intended to maintain the global momentum recently exemplified by calls for action (Darwall et al., 2018), such as the Emergency Recovery Plan for freshwater biodiversity (Tickner et al., 2020). This includes mobilising practitioners (Twardek et al., 2021), promoting strategic activities (Arthington, 2021) and embracing the 25 essential questions to inform the protection and restoration of freshwater biodiversity (Harper et al., 2021). Our succinct and clear agenda comes at a pivotal time when governments around the world are revising major international agreements relevant to biodiversity conservation, such as the Sustainable Development Goals, or are at the brink of major conventions including the Convention on Biological Diversity and the UN Framework Convention on Climate Change. We are convinced these 15 priority needs are critical for the successful protection and recovery of freshwater biodiversity globally. Therefore, we call upon scientists, conservation practitioners, environmental managers and policymakers to support this agenda and implement it by developing local, regional and global actions that offer concrete responses to halt the loss and improve the recovery of freshwater biodiversity.

\section{ACKNOWLEDGEMENTS}

This manuscript is a contribution of the Alliance for Freshwater Life (www.allianceforfreshwaterlife.org). We thank Nick Bond, Lisa Bossenbroek, Lekima Copeland, Dean Jacobsen, Maria Cecilia Londoño, David Lopez, Jaime Ricardo Garcia Marquez, Ketlhatlogile Mosepele, Nunia Thomas-Moko, Qiwei Wei and the authors of Living Waters: A Research Agenda for the Biodiversity of Inland and Coastal Waters for their contributions. We also thank Peter Thrall, Ian Harrison and two anonymous referees for their valuable comments that helped improve the manuscript. Open access funding enabled and organised by Projekt DEAL.

\section{AUTHOR CONTRIBUTIONS}

AM led the writing and development of the manuscript with significant contributions from HPG, JMJ, MTM, MOG, SD and SCJ. SCJ led the consultation that resulted in this agenda with significant contributions from JMJ, MTM, SD, RBS, FL and DH. All authors contributed to writing and revising the manuscript.

\section{PEER REVIEW}

The peer review history for this article is available at https://publons.com/publon/10.1111/ele.13931.

\section{DATA AVAILABILITY STATEMENT}

The article provides no data.

\section{ORCID}

Alain Maasri (1) https://orcid.org/0000-0003-1236-8374

Sonja C. Jähnig (1) https://orcid.org/0000-0002-6349-9561

Mihai C. Adamescu (10) https://orcid.org/0000-0002-3056-8444

Rita Adrian (D) https://orcid.org/0000-0002-6318-7189

Donald J. Baird (1) https://orcid.org/0000-0003-4653-7906

Angelica Batista-Morales (10) https://orcid.

org/0000-0002-8457-0830

Núria Bonada (1) https://orcid.org/0000-0002-2983-3335

Lee E. Brown (1) https://orcid.org/0000-0002-2420-0088

Viola Clausnitzer (10) https://orcid.org/0000-0002-9168-2419

Steven J. Cooke (1) https://orcid.org/0000-0002-5407-0659

Thibault Datry (D) https://orcid.org/0000-0003-1390-6736

Luc De Meester (10) https://orcid.org/0000-0001-5433-6843

Sami Domisch (D) https://orcid.org/0000-0002-8127-9335

David Dudgeon (10 https://orcid.org/0000-0003-4632-3473

Tibor Erös (D) https://orcid.org/0000-0002-2252-3115

Hendrik Freitag (1) https://orcid.org/0000-0002-1325-0979

Juergen Geist (D) https://orcid.org/0000-0001-7698-3443

Mark O. Gessner (1) https://orcid.org/0000-0003-2516-7416

Christopher Gordon (1) https://orcid.org/0000-0003-2734-851X

Pablo E. Gutiérrez-Fonseca (10 https://orcid.

org/0000-0003-0777-8889

Peter Haase (1) https://orcid.org/0000-0002-9340-0438 
Hans Jürgen Hahn (1D https://orcid.org/0000-0002-2157-8712

Fengzhi He (1) https://orcid.org/0000-0002-7594-8205

Jani Heino (1) https://orcid.org/0000-0003-1235-6613

Franz Hölker (1) https://orcid.org/0000-0001-5932-266X

Jonathan M. Jeschke (10 https://orcid.org/0000-0003-3328-4217

Richard K. Johnson (10 https://orcid.org/0000-0001-7979-6563

Gregor Kalinkat (10) https://orcid.org/0000-0003-3529-5681

Bakhtiyor K. Karimov (1) https://orcid.org/0000-0003-0545-4733

Aventino Kasangaki (1) https://orcid.org/0000-0002-9762-4666

Ismael A. Kimirei (10) https://orcid.org/0000-0002-1101-5262

Bert Kohlmann (1) https://orcid.org/0000-0002-3441-3933

Mathias Kuemmerlen (10 https://orcid.org/0000-0003-1362-3701

Benjamin Kupilas (1) https://orcid.org/0000-0002-4211-1679

Simone D. Langhans (D) https://orcid.org/0000-0001-9581-3183

Florian Leese (10) https://orcid.org/0000-0002-5465-913X

Francis S. Magbanua (1D https://orcid.org/0000-0001-7373-373X

Shin-ichiro S. Matsuzaki iD https://orcid.org/0000-0003-2744-1343

Michael T. Monaghan (1D https://orcid.org/0000-0001-6200-2376

Levan Mumladze (1) https://orcid.org/0000-0002-2172-6973

Javier Muzon (1) https://orcid.org/0000-0002-3956-1986

Clifford Ochs (10 https://orcid.org/0000-0002-9032-8901

Oghenekaro Nelson Odume (1) https://orcid.

org/0000-0001-5220-3254

Alonso Ramírez (D) https://orcid.org/0000-0001-9985-5719

Bindiya Rashni (D) https://orcid.org/0000-0002-7699-9549

Vere Ross-Gillespie (1) https://orcid.org/0000-0003-0867-124X

Ralf B. Schäfer (10 https://orcid.org/0000-0003-3510-1701

Astrid Schmidt-Kloiber (D) https://orcid.

org/0000-0001-8839-5913

Ole Seehausen (1D https://orcid.org/0000-0001-6598-1434

Janne Soininen (1D https://orcid.org/0000-0002-8583-3137

Jason D. Stockwell @ https://orcid.org/0000-0003-3393-6799

Rebecca E. Tharme (1) https://orcid.org/0000-0001-5789-1316

James H. Thorp (10) https://orcid.org/0000-0003-2757-9860

David Tickner (10) https://orcid.org/0000-0001-5928-0869

Klement Tockner (1) https://orcid.org/0000-0002-0038-8151

Jonathan D. Tonkin (1) https://orcid.org/0000-0002-6053-291X

Mireia Valle (1) https://orcid.org/0000-0001-8517-8518

Martin Volk (1) https://orcid.org/0000-0003-0064-8133

Ding Wang (1) https://orcid.org/0000-0001-5867-2035

Christian Wolter (D) https://orcid.org/0000-0002-2819-2900

Susanne Worischka (D) https://orcid.org/0000-0001-6453-3314

\section{REFERENCES}

Alberti, M., Palkovacs, E., Roches, S., Meester, L., Brans, K., Govaert, L. et al. (2020) The complexity of urban eco-evolutionary dynamics. BioScience, 70, 772-793.

Arthington, A.H. (2021) Grand challenges to support the freshwater biodiversity emergency recovery plan. Frontiers in Environmental Science, 9. https://doi.org/10.3389/ fenvs.2021.664313

Baird, D. \& Hajibabaei, M. (2012) Biomonitoring 2.0: a new paradigm in ecosystem assessment made possible by next-generation DNA sequencing. Molecular Ecology, 21, 2039-2044.

Ball-Damerow, J.E., Brenskelle, L., Brave, N., Soltis, P.S., Sierwald, P., Bieler, R. et al. (2019) Research applications of primary biodiversity databases on the digital age. PLoS One, 14, e0215794.

Birk, S., Chapman, D., Carvalho, L., Spears, B.M., Andersen, H.E., Argillier, C. et al. (2020) Impacts of multiple stressors on freshwater biota across spatial scales and ecosystems. Nature Ecology \& Evolution, 4, 1060-1068.

Buck, M. \& Hamilton, C. (2011) The Nagoya protocol on access to genetic resources and the fair and equitable sharing of benefits arising from their utilization to the convention on biological diversity. Review of European Community \& International Environmental Law, 20, 47-61.

Chambers, J.M., Wyborn, C., Ryan, M.E., Reid, R.S., Riechers, M., Serban, A. et al. (2021) Six modes of co-production for sustainability. Nature Sustainability, 4, 983-996. https://doi.org/10.1038/ s41893-021-00755-x

Darwall, W., Bremerich, V., De Wever, A., Dell, A.I., Freyhof, J., Gessner, M.O. et al. (2018) The Alliance for Freshwater Life: a global call to unite efforts for freshwater biodiversity science and conservation. Aquatic Conservation: Marine and Freshwater Ecosystems, 28, 1015-1022. https://doi.org/10.1002/ aqc. 2958

Díaz, S., Pascual, U., Stenseke, M., Martín-López, B., Watson, R.T., Molnár, Z. et al. (2018) Assessing nature's contributions to people. Science, 359, 270-272.

Dudgeon, D. (2010) Prospects for sustaining freshwater biodiversity in the 21st century: linking ecosystem structure and function. Current Opinion in Environmental Sustainability, 2, 422-430.

Dudgeon, D., Arthington, A.H., Gessner, M.O., Kawabata, Z.-I., Knowler, D.J., Lévêque, C. et al. (2006) Freshwater biodiversity: importance, threats, status and conservation challenges. Biological Reviews, 81, 163-182.

Eitzel, M.V., Cappadonna, J.L., Santos-Lang, C., Duerr, R.E., Virapongse, A., West, S.E. et al. (2017) Citizen science terminology matters: exploring key terms. Citizen Science: Theory and Practice, 2, 1-20. https://doi.org/10.5334/cstp.96

Fritz, S., See, L., Carlson, T., Haklay, M., Oliver, J.L., Fraisl, D. et al. (2019) Citizen science and the United Nations Sustainable Development Goals. Nature Sustainability, 2, 922-930. https:// doi.org/10.1038/s41893-019-0390-3

Geist, J. \& Hawkins, S.J. (2016) Habitat recovery and restoration in aquatic ecosystems: current progress and future challenges. Aquatic Conservation: Marine and Freshwater Ecosystems, 26, 942-962.

Harper, M., Mejbel, H.S., Longert, D., Abell, R., Beard, T.D., Bennett, J.R. et al. (2021) Twenty-five essential research questions to inform the protection and restoration of freshwater biodiversity. Aquatic Conservation: Marine and Freshwater Ecosystems, 31, 2632-2653.

Hawkins, C.P. \& Yuan, L.L. (2016) Multitaxon distribution models reveal severe alteration in the regional biodiversity of freshwater invertebrates. Freshwater Science, 35, 1365-1376.

Heino, J., Alahuhta, J., Bini, L.M., Cai, Y., Heiskanen, A.-S., Hellsten, S. et al. (2021) Lakes in the era of global change: moving beyond single-lake thinking in maintaining biodiversity and ecosystem services. Biological Reviews, 96, 89-106.

Heino, J., Culp, J.M., Erkinaro, J., Goedkoop, W., Lento, J., Rühland, K.M. et al. (2020) Abruptly and irreversibly changing Arctic freshwaters urgently require standardized monitoring. Journal of Applied Ecology, 57, 1192-1198.

Heino, J., Virkkala, R. \& Toivonen, H. (2009) Climate change and freshwater biodiversity: detected patterns, future trends and adaptations in northern regions. Biological Reviews, 84, 39-54.

Humphries, P. \& Winemiller, K.O. (2009) Historical impacts on river fauna, shifting baselines, and challenges for restoration. BioScience, 59, 673-684.

IPBES. (2016) The methodological assessment report on scenarios and models of biodiversity and ecosystem services (Ferrier, S., Ninan, K.N., Leadley, P., Alkemade, R., Acosta, L.A., Akçakaya, H.R., Brotons, L., Cheung, W.W., Christensen, V., Harhash, K.A. \& Kabubo-Mariara, J., Eds.). Bonn, Germany: Secretariat of the Intergovernmental Platform for Biodiversity and Ecosystem Services.

IPBES. (2019). Summary for policymakers of the global assessment report of the intergovernmental science-policy platform 
on biodiversity and ecosystem services (Díaz, S., Settele, J., Brondízio, E.S., Ngo, H.T., Guèze, M., Agard, J., Arneth, A., Balvanera, P., Brauman, K.A., Butchart, S.H.M., Chan, K.M.A., Garibaldi, L.A., Ichii, K., Liu, J., Subramanian, S.M., Midgley, G.F., Miloslavich, P., Molnár, Z., Obura, D., Pfaff, A., Polasky, S., Purvis, A., Razzaque, J., Reyers, B., Roy Chowdhury, R., Shin, Y.J., Visseren-Hamakers, I.J., Willis, K.J. \& Zayas, C.N., Eds.). Bonn, Germany: Secretariat of the Intergovernmental Platform for Biodiversity and Ecosystem Services.

Kelly, M. (2019) Rapid evolution generates synergism between multiple stressors: linking theory and an evolution experiment. Philosophical Transactions of the Royal Society B, 374, 20180176.

Kim, H., Peterson, G., Cheung, W.W.L., Ferrier, S., Alkemade, R., Arneth, A. et al. (2021). Towards a better future for biodiversity and people: modeling Nature Futures. SocArXiv. https://doi. org/10.31235/osf.io/31293sqp.

Konno, K.O., Akasaka, M., Koshida, C., Katayama, N., Osada, N., Spake, R. et al. (2020) Ignoring non-English-language studies may bias ecological meta-analyses. Ecology and Evolution, 10, 6373-6384.

Lu, W., Font, R.A., Cheng, S., Wang, J. \& Kollmann, J. (2019) Assessing the context and ecological effects of river restoration-a metaanalysis. Ecological Engineering, 136, 30-37.

McKinley, D.C., Miller-Rushing, A.J., Ballard, H.L., Bonney, R., Brown, H., Cook-Patton, S.C. et al. (2017) Citizen science can improve conservation science, natural resource management, and environmental protection. Biological Conservation, 208, 15-28.

Merilä, J. \& Hendry, A.P. (2014) Climate change, adaptation, and phenotypic plasticity: the problem and the evidence. Evolutionary Applications, 7, 1-14.

Mlot, C. (2004) Microbial diversity unbound: what DNA-based techniques are revealing about the planet's hidden biodiversity. BioScience, 54, 1064-1068.

Moralis, D. (2021) Environmental funding by European foundations, Volume 5 (Centre, E.F., Ed.). Brussels, Belgium: European Foundation Centre.

Nesshöver, C., Livoreil, B., Schindler, S. \& Vandewalle, M. (2016) Challenges and solutions for networking knowledge holders and better informing decision-making on biodiversity and ecosystem services. Biodiversity and Conservation, 25, 1207-1214.

Norström, A.V., Cvitanovic, C., Löf, M.F., West, S., Wyborn, C., Balvanera, P. et al. (2020) Principles for knowledge co-production in sustainability research. Nature Sustainability, 3, 182-190.

Orr, J.A., Luijckx, P., Arnoldi, J.-F., Jackson, A.L. \& Piggot, J.J. (2021) Rapid evolution generates synergies between multiple stressors: linking theory and an evolution experiment. Global Change Biology. https://doi.org/10.1111/gcb.15633

Pereira, L.M., Davies, K.K., Belder, E., Ferrier, S., KarlssonVinkhuyzen, S., Kim, HyeJin et al. (2020) Developing multiscale and integrative nature-people scenarios using the Nature Futures Framework. People and Nature, 2, 1172-1195.

Reid, A.J., Carlson, A.K., Creed, I.F., Eliason, E.J., Gell, P.A., Johnson, P.T.J. et al. (2019) Emerging threats and persistent conservation challenges for freshwater biodiversity. Biological Reviews, 94, 849-873.

Rimet, F., Aylagas, E., Borja, Á., Bouchez, A., Canino, A., Chauvin, C. et al. (2021) Metadata standards and practical guidelines for specimen and DNA curation when building barcode reference libraries for aquatic life. Metabarcoding and Metagenomics, 5, 11-33.

Rosa, I.M.D., Pereira, H.M., Ferrier, S., Alkemade, R., Acosta, L.A., Akcakaya, H.R. et al. (2017) Multiscale scenarios for nature futures. Nature Ecology \& Evolution, 1, 1416-1419.
Soga, M. \& Gaston, K.J. (2018) Shifting baseline syndrome: causes, consequences, and implications. Frontiers in Ecology and the Environment, 16, 222-230

Stephenson, P.J. \& Stengel, C. (2020) An inventory of biodiversity data sources for conservation monitoring. PLoS One, 15, e0242923.

Thieme, M.L., Tickner, D., Grill, G., Carvallo, J.P., Goichot, M., Hartmann, J. et al. (2021) Navigating trade-offs between dams and river conservation. Global Sustainability, 4, E17.

Tickner, D., Opperman, J.J., Abell, R., Acreman, M., Arthington, A.H., Bunn, S.E. et al. (2020) Bending the curve of global freshwater biodiversity loss: an emergency recovery plan. BioScience, 70, 330-342.

Tonkin, J.D., Poff, N.L., Bond, N.R., Horne, A., Merritt, D.M., Reynolds, L.V. et al. (2019) Prepare river ecosystems for an uncertain future. Nature, 570, 301-303.

Turak, E., Harrison, I., Dudgeon, D., Abell, R., Bush, A., Darwall, W. et al. (2017) Essential biodiversity variables for measuring change in global freshwater biodiversity. Biological Conservation, 213, 272-279.

Twardek, W.M., Nyboer, E.A., Tickner, D., O'Connor, C.M., Lapointe, N.W.R., Taylor, M.K. et al. (2021) Mobilizing practitioners to support the Emergency Recovery Plan for freshwater biodiversity. Conservation Science and Practice, 3(8), e467.

Urban, M.C., Bocedi, G., Hendry, A.P., Mihoub, J.-B., Pe'er, G., Singer, A. et al. (2016) Improving the forecast for biodiversity under climate change. Science, 353, aad8466.

Vári, A., Podschun, S.A., Erös, T., Heim, T., Pataki, B., Iojă, I.-C. et al. (2021) Freshwater systems and ecosystem services: challenges and chances for cross-fertilization of disciplines. Ambio. https:// doi.org/10.1007/s13280-021-01556-4

Wilkinson, M.D., Dumontier, M., Aalbersberg, I.J., Appleton, G., Axton, M., Baak, A. et al. (2016) The FAIR guiding principles for scientific data management and stewardship. Scientific Data, 3,160018 .

WWF. (2020) Living planet report 2020. Bending the curve of biodiversity loss: a deep dive into freshwater (Almond, R.E.A., Grooten, M. \& Petersen, T., Eds.). Gland, Switzerland: World Wildlife Fund.

Zarfl, C., Berlekamp, J., He, F., Jähnig, S.C., Darwall, W. \& Tockner, K. (2019) Future large hydropower dams impact global freshwater megafauna. Scientific Reports, 9, 18531.

\section{SUPPORTING INFORMATION}

Additional supporting information may be found in the online version of the article at the publisher's website.

How to cite this article: Maasri, A., Jähnig, S.C., Adamescu, M.C., Adrian, R., Baigun, C., Baird, D.J., et al. (2021) A global agenda for advancing freshwater biodiversity research. Ecology Letters, 00, 1-9. Available from: https://doi.org/10.1111/ ele. 13931 